\title{
Developing Entrepreneurial Interest and Student Independence through Project- Based Entrepreneurship Learning
}

\section{Mengembangkan Minat Wirausaha dan Kemandirian Mahasiswa melalui Pembelajaran Kewirausahaan Berbasis Proyek}

\author{
Eni Erwantiningsih ${ }^{1 *}$, Hari Wahyuni ${ }^{2}$, Waladi Immadudin ${ }^{3}$ \\ Fakultas Ekonomi, Universitas Merdeka Pasuruan, Indonesia
}

\section{OPEN ACCESS}

ISSN 25482254 (online)

ISSN 20893833 (print)

Edited by:

Mahardika Darmawan Kusuma

Wardana

Reviewedby:

Deni Adi Putra

${ }^{*}$ Correspondence:

Eni Erwantiningsih

enierwanti232@gmail.com

Received: 8 Mei 2021

Accepted: 9 Juni 2021

Published: 2 Agustus 2021

Citation:

Erwantiningsih E, Wahyuni $H$

and Immadudin W (2021)

Developing Entrepreneurial

Interest and Student

Independence through Project-

Based Entrepreneurship

Learning.

Pedagogia: Jurnal Pendidikan. 10:2. doi:

10.21070/pedagogia.v10vi2i. 1255
The purpose of this study was to determine (1) How the contribution of project-based entrepreneurship learning; (2) What is the student's entrepreneurial interest; (3) How independent are students; (4) How does project-based entrepreneurship learning affect students' entrepreneurial interest and independence. The method in this research is quantitative survey. According to the results of the study, the t-count value is 5.517 and the t-table number is 2.002 , so that $t$-count $>$ t-table, which means that there is a significant influence between Project-Based Learning on Entrepreneurial Interest, while the magnitude of the influence is obtained a coefficient value of 0.669 for the effect of learning. project based on entrepreneurial interest. Meanwhile, for the effect of entrepreneurship learning on student independence, the t-count is 5.993 and the $\mathrm{t}$-table number is 2.002 , so that $\mathrm{t}$-count> $\mathrm{t}$-table. This means that there is a significant influence between project-based learning on independence. There is also a coefficient value of 0.696 , which means that when there is an increase in projectbased learning, it will increase Independence by 0.696 . Meanwhile, the correlation coefficient value is 0.618 and the coefficient of determination (R2) is 0.382 . This means that there is an influence between the Project-Based Learning variable on Independence of $38.2 \%$ while the remaining $61.8 \%$ is influenced by other variables that the researchers did not involve in this study.

Keywords: Project-Based Learning, Entrepreneurial Interest, Independence

Tujuan dari penelitian ini adalah untuk mengetahui (1) Bagaimana kontribusi pembelajaran kewirausahaan yang berbasis proyek; (2) Bagaimana minat wirausaha; 
(3) Seberapa mandiri siswa; (4) Bagaimana pengaruh pembelajaran kewirausahaan berbasis proyek terhadap minat dan kemandirian berwirausaha siswa. Metode dalam penelitian ini adalah survei kuantitatif. Berdasarkan hasil penelitian diperoleh nilai t hitung sebesar 5,517 dan nilai t tabel sebesar 2,002 sehingga t hitung $>t$ tabel yang artinya terdapat pengaruh yang signifikan antara Project Based Learning terhadap Minat Berwirausaha, sedangkan besarnya pengaruh diperoleh nilai koefisien sebesar 0,669 untuk pengaruh pembelajaran. proyek berdasarkan minat kewirausahaan. Sedangkan untuk pengaruh pembelajaran kewirausahaan terhadap kemandirian siswa diperoleh $t$ hitung sebesar 5,993 dan nilai t tabel sebesar 2,002, sehingga t hitung $>t$ tabel. Artinya ada pengaruh yang signifikan antara pembelajaran berbasis proyek terhadap kemandirian. Terdapat pula nilai koefisien sebesar 0,696 yang artinya apabila terjadi peningkatan pembelajaran berbasis proyek maka akan meningkatkan kemandirian sebesar 0,696. Sedangkan nilai koefisien korelasi sebesar 0,618 dan koefisien determinasi (R2) sebesar 0,382. Artinya terdapat pengaruh antara variabel Project Based Learning terhadap Kemandirian sebesar 38,2\% sedangkan sisanya 61,8\% dipengaruhi oleh variabel lain yang tidak peneliti libatkan dalam penelitian ini..

Kata Kunci: Pembelajaran Berbasis Proyek, Minat Berwirausaha, Kemandirian 


\section{PENDAHULUAN}

Kemajuan perekonomian suatu negara sangat tergantung dari peran serta semua warga negaranya. Apabila setiap warga negaranya mandiri serta mengembangkan kreatifitas dan inovasinya maka dia akan mampu memperbaiki kondisi perekonomiannya yang tentu akan berakibat positif terhadap lingkungannya. Pengembangan ekonomi dapat dicapai dengan kerjasama dari pemerintah, swasta juga masyarakat Mashuri et al., (2020). Pemuda sebagai generasi penerus merupakan ujung tombak kemajuan bangsa dalam hal ini kemandirian perekonomian. Dalam hal ini mahasiswa selayaknya mengasah pengetahuan, ketrampilan serta kemandiriannya agar bisa membuka peluang usaha dan tidak mengandalkan hanya menjadi karyawan sebuah perusahaan atau aparatur sipil negara. Semakin tinggi pendidikan maka mereka akan lebih memilih pekerjaan yang memberikan keamanan dimasa mendatang serta adanya perhitungan pengembalian biaya pendidikan selama ini. Takdir et al., (2015).

Fakta dilapangan berdasarkan data statistik yang diupdate pada tanggal 15 Maret 2021 bahwa jumlah penduduk kota Pasuruan 208.006 jiwa dengan laju pertumbuhan tahun 20102020 sebesar 1,08 persen per tahun. Sementara data per Pebruari 2021 bahwa jumlah pencari kerja sebanyak 1.271 dengan lowongan kerja yang tersedia hanya 541 buah. Sementara usaha mikro kecil menurut skala UMK dan lapangan usaha di Kota Pasuruan tahun 2016 sejumlah 31.668. Hal ini mengindikasikan bahwa jumlah kewirausahaan di Kota Pasuruan 34,8 \% saja. Perkembangan jumlah usaha mikro ini sangat memprihatinkan dibanding dengan laju pertumbuhan penduduk usia produktif yang seharusnya berpotensi menopang pertumbuhan perekonomian dari sektor UMKM. Mahasiswa yang menempati proporsi usia produktif ini memang masih sedikit sekali yang mengisi kekosongan peluang usaha ekonomi mikro kecil tersebut. Ide kreatif dan inovatif serta ketrampilan yang sangat diharapkan oleh daerah masih belum dirasakan dengan maksimal.

Salah satu pola hidup yang diterapkan dengan pemaksimalan kemampuan diri serta kreatifitas salah satunya adalah dengan berwirausaha. Dengan wirausaha mereka tidak tergantung dengan tempatnya bekerja, mereka bisa menggali peluang serta kesempatan di lingkungan yang saat ini sedang dibutuhkan orang lain. Karena seorang wirausaha mampu melihat peluang dan menterjemahkan peluang tersebut sebagai sebuah kesempatan Suryana (2003). Pendidikan kewirausahaan sangat berperan dalam mengasah bakat dan minat seseorang dalam berwirausaha. Pembelajaran tentang kewirausahaan memiliki pengaruh terhadap minat mahasiswa sebesar 41,8\%. Satrionugroho \& Nugroho (2015). Penelitian terkait menjelaskan bahwa tidak terdapat perbedaan yang signifikan dirasakan oleh mahasiswa baik sebelum maupun sesudah mengikuti pembelajaran kewirausahaan. Budi \& Fensi (2018). Hal ini memunculkan sebuah pertanyaan bahwa ada faktor lain yang dapat mempengaruhi minat belajar. Penelitian terkait metode pembelajaran ini dilakukan dan memberikan wacana bahwa metode belajar mempengaruhi hasil belajar Prihatini (2017). Penelitian lain juga membuktikan bahwa metode pembelajaran yang tepat dapat mempengaruhi minat dan prestasi Maesaroh (2013). Metode pembelajaran berbasis proyek juga efektif untuk meningkatkan sikap serta minat wirausaha Mulyani (2014).

Adanya perbedaan hasil penelitian tersebut melahirkan sebuah pemikiran terkait hal mendasar yang bisa meningkatkan minat mahasiswa dalam berwirausaha. Beberapa Perguruan Tinggi belum bisa maksimal menghasilkan output mahasiswa yang berkompeten dan mampu bertahan dalam persaingan di dunia kerja. Beberapa penelitian yang dilakukan dalam rangka untuk mengetahui pendekatan pembelajaran yang tepat untuk mencetak mahasiswa yang kompeten serta mempunyai kemampuan dalam berwirausaha sebagai modal menghadapi persaingan di masyarakat. Sangat perlu sekali menerapkan model pembelajaran inovatif yaitu berbasis proyek dimana sistem pembelajaran dengan melibatkan proyek dan bekerja mandiri dalam membangun pembelajarannya dan mengaplikasikan dalam hasil kerja nyata. Hanafiah \& Suhana (2009) Sedangkan pendapat yang lain bahwa pembelajaran berbasis proyek sebagai metode belajar dengan memberikan kebebasan dalam berpikir terkait bahan pengajaran serta tujuan yang ingin dicapai. Daryanto (2009) Penelitian lain dilakukan dengan diperoleh suatu kesimpulan bahwa model pembelajaran kewirausahaan berbasis proyek mampu menumbuhkan semangat wirausaha mahasiswa. Farida et al., (2017) Sejalan dengan penelitian di atas yang dilakukan pula disimpulkan bahwa model pembelajaran berbasis proyek memberikan kontribusi peningkatan minat berwirausaha melalui pembentukan karakter kepemimpinan dan keberanian mengambil resiko. Sulasari (2016) Penelitian dilakukan dengan memberikan kesimpulan bahwa model pembelajaran berbasis proyek dengan pendekatan chemoentrepreneurship dapat meningkatkan minat wirausaha Inayah et al., (2019). Perguruan tinggi sebagai salah satu lembaga yang memiliki peran besar dalam memberikan wawasan serta mengarahkan mahasiswa sebagai generasi muda penerus bangsa dan pejuang perekonomian. Sudah seharusnya mahasiswa ke depan adalah sebagai pencetak lowongan pekerjaan dan bukan hanya sebagai pencari kerja. Sesuai dengan hasil penelitian lainnya bahwa Universitas mempunyai peran sebagai sumber informasi terkait cerahnya peluang yang akan diperoleh apabila mahasiswa menjadi wirausaha, memberikan pengetahuan kewirausahaan serta menyiapkan wadah bagi mahasiswa apabila akan menerapkan ilmunya dalam sebuah praktek bisnis sederhana di Universitas.

Berdasarkan latar belakang di atas, pembelajaran kewirausahaan berbasis proyek yang mengedepankan aplikasi pembelajaran dan tidak hanya teori saja sangat tepat untuk bertahan dalam situasi perekonomian yang semakin sulit, sehingga dapat dirumuskan permasalahan apakah ada peningkatan minat mahasiswa untuk berwirausaha serta sikap mandiri yang terbentuk dari model pembelajaran dengan berbasis proyek. Tujuan penelitian ini adalah untuk mengembangkan minat mahasiswa sebagai wirausaha serta membentuk sikap mandiri melalui kombinasi pemberian bahan ajar dengan menggunakan metode pembelajaran berbasis proyek yaitu mengaplikasikan pengetahuan kewirausahaan yang telah diperoleh dengan praktek usaha secara riel.

\section{METODE}

Penelitian ini menggunakan pendekatan kuantitatif dengan 
metode regresi linier berganda, yaitu terdapat variabel bebas dan variabel terikat. Tujuan penelitian ini adalah untuk mengetahui kemampuan serta pemahaman mahasiswa dalam mata kuliah kewirausahaan dengan metode pembelajaran berbasis proyek. Obyek penelitian ini adalah seluruh mahasiwa prodi manajemen angkatan 2017/2018 dan yang mengikuti perkuliahan lab kewirausahaan pada semester Genap tahun akademik 2019/2020. Penarikan sampel untuk responden dilakukan keseluruhan atau sampel jenuh. Teknik pengambilan menggunakan metode sensus dengan cara semua populasi yang ada dijadikan sampel berjumlah 60 mahasiswa. Instrumen yang digunakan yaitu lembar pengamatan yang berisi kriteria penilaian yang diisi oleh peneliti selama penelitian meliputi perencanaan usaha, pelaksanaan serta evaluasi hasil praktek wirausaha mahasiswa. Selain itu digunakan lembar sikap mahasiswa yang nerupakan lembar penilaian untuk menilai sejauh mana pandangan, sikap dan antusiasme mahasiswa selama pembelajaran pada saat penelitian dilaksanakan.

Jenis tes yang digunakan adalah post test yaitu diberikan setelah mahasiswa mengikuti proses pembelajaran. Sedangkan kuesioner diberikan kepada mahasiswa untuk mengetahui pernyataan baik positif maupun negatif terkait pemahaman materi serta pengaplikasiannya dalam proyek yang dilaksanakan di akhir proses pembelajaran. Diharapkan dapat diketahui bagaimana pendapat dan kesulitan serta manfaat apabila diberikan kesempatan untuk menuangkan pemikiran, ide serta pemecahan masalah apabila diperlukan. Pengumpulan data pada penelitian ini menggunakan kuesioner dan observasi. Observasi dilakukan untuk memperoleh gambaran kondisi pemahaman mahasiswa pada awal perkuliahan serta informasi pada saat kegiatan pembelajaran selama penelitian. Sedangkan pengumpulan data kuesioner dengan cara disebarkan kepada responden melalui google form. Skala likert merupakan skala yang akan digunakan oleh peneliti dalam kuesioner.

Pada penelitian ini dokumentasi diperoleh dari lembar pengamatan selama kegiatan pembelajaran, nilai post test serta hasil analisis pengolahan data penelitian berdasar hasil pengisian kuesioner oleh mahasiswa. Teknik analisis data dengan menggunakan analisis data deskriptif kuantitatif. Teknik analisis data yang digunakan dalam penelitian ini adalah analisis data deskriptif kuantitatif. Dari hasil analisis data yang diperoleh akan dideskripsikan dalam bentuk narasi pada hasil penelitian. Variabel bebas dalam penelitian ini adalah Pembelajaran Kewirausahaan Berbasis Proyek sedangkan variabel terikat adalah minat berwirausaha (X1) dan Kemandirian (X2) yang selanjutnya akan dianalisis pengaruh variabel bebas pada masing - masing variabel terikat tersebut. Desain penelitian dapat dilihat berikut ini;

[Figure 1 about here.]

\section{HASIL DAN PEMBAHASAN}

Tujuan dari penelitian ini adalah untuk membuktikan adanya pengaruh pembelajaran mata kuliah kewirausahaan dengan mengaplikasikan metode berbasis proyek terhadap pengembangan minat wirausaha serta kemandirian mahasiswa sebagai upaya bertahan di masa pandemic covid19. Metode pembelajaran ini dengan mengkombinasikan pemberian bahan ajar wirausaha di dalam kelas serta praktek di lapangan dari proses membuat rencana bisnis, rencana keuangan dalam usaha, membuat produk sampai kepada proses pemasaran yang di laporkan dalam bentuk laporan keuangan usaha.

\section{Pembelajaran Berbasis Proyek}

Pembelajaran mata kuliah kewirausahaan tidak memberikan perubahan manfaat sebelum dan sesudah belajar sehingga hanya merupakan sebuah ilmu semata Budi \& Fensi (2018). Hal ini mendasari bagaimana sebaiknya jalan keluar tentang metode belajar yang sesuai dengan minat serta gaya belajar mahasiswa yang bisa memberikan motivasi dan semangat untuk belajar dan menghasilkan manfaat tidak hanya akademis tapi juga pengalaman di lapangan. Berdasarkan hasil olah data diperoleh suatu gambaran deskriptif bahwa dari beberapa indikator yang diujikan terdapat kesimpulan bahwa terdapat $8,13 \%$ mahasiswa merasakan manfaat pembelajaran dengan mengaplikasi ilmu dalam sebuah praktek nyata yaitu mereka diberikan kesempatan untuk memperlihatkan kemampuannya dalam mengembangkan ide dan pemikiran usaha ke depan.

[Figure 2 about here.]

[Table 1 about here.]

\section{Minat Wirausaha}

Berdasarkan hasil pengolahan data statistik bahwa pembelajaran kewirausahaan dengan berbasis proyek mampu merangsang serta meningkatkan minat mahasiswa untuk berwirausaha. Menurut hasil uji data deskripsi diperoleh data bahwa dari indikator yang diujikan diperoleh gambaran bahwa sebanyak 12,25\% mahasiswa mempunyai ketertarikan dan berminat untuk berwirausaha setelah lulus kuliah. Hal ini menunjukkan bahwa tidak semua bertujuan hanya menjadi karyawan suatu lembaga saja bahkan dari data diperoleh mahasiswa yang sudah menjadi seorang karyawan juga masih beminat menjadi seorang wirausaha.

[Figure 3 about here.]

[Figure 4 abouthere.]

[Table 2 about here.]

[Table 3 about here.]

Menurut hasil perhitungan dengan menggunakan SPSS bahwa pada uji determinasi diperoleh kesimpulan bahwa ada pengaruh pembelajaran berbasis proyek terhadap minat wirausaha usaha sebesar $34,4 \%$ sedangkan sisanya $65,6 \%$ dipengaruhi oleh variabel-variabel lain yang tidak peneliti libatkan dalam penelitian ini.

[Table 4 about here.] 
[Figure 4 about here.]

Hal ini sejalan dengan penelitian terdahulu yang memberikan kesimpulan bahwa model pembelajaran kewirausahaan berbasis proyek mampu menumbuhkan semangat wirausaha mahasiswa. Farida et al., (2017). Penelitian terkait juga disimpulkan bahwa model pembelajaran berbasis proyek memberikan kontribusi peningkatan minat berwirausaha melalui pembentukan karakter kepemimpinan dan keberanian mengambil resiko Sulasari (2016). Sementara itu diketahui pula bahwa model pembelajaran berbasis proyek dengan pendekatan chemoentrepreneurship dapat meningkatkan minat wirausaha Inayah etal., (2019). Minat untuk berwirausaha memang harus diasah dan dibentuk melalui materi ajar yang diberikan selama proses perkuliahan, akan tetapi pengetahuan yang diperoleh dalam proses pembelajaran seharusnya memberikan hasil nyata dalam perubahan kehidupan mahasiswa. Pengetahuan agar bisa maksimal diperoleh tentunya dilakukan dengan cara yang komunikatif serta menyenangkan dan ada bukti nyata untuk mengaplikasikannya.

\section{Kemandirian Mahasiswa}

Minat dan bakat wirausaha mahasiswa dapat diasah melalui proses belajar di perkuliahan serta implementasi dalam praktek kerja nyata. Apabila mahasiswa memiliki minat dan siap untuk menjadi seorang wirausaha maka diharapkan ada sikap mandiri yang terbentuk untuk bisa mengatasi dan bertahan di tengah kesulitan perekonomian di masa pandemi covid-19 ini. Berdasarkan hasil uji deskriptif pada indikator tentang kemandirian diperoleh kesimpulan bahwa sebanyak 20,53\% mahasiswa merasa tertantang untuk menyelesaikan setiap tugas selama proses pembelajaran kewirausahaan. Mereka merasakan keinginan untuk membuktikan bahwa mereka mampu dan mandiri dalam menyelesaikan tugas.

\section{[Figure 5 about here.]}

Menurut hasil olah data dengan SPSS diperoleh koefisien determinasi sebesar 0,382 sehingga disimpulkan bahwa pembelajaran berbasis proyek terhadap kemandirian sebesar $38,2 \%$ sedangkan sisanya $61,8 \%$ dipengaruhi variabel diluar penelitian ini.

[Table 5 about here.]

[Figure 6 about here.]

Hal ini sejalan dengan penelitian terdahulu bahwa pembelajaran inovatif yaitu dengan melibatkan proyek serta mandiri dan diaplikasikan dengan hasil kerja nyata Hanafiah \& Suhana (2009). Hasil penelitian selanjutnya bahwa metode belajar berbasis proyek dapat memberikan kebebasan berpikir terkait bahan ajar dan tujuan yang ingin dicapai Daryanto (2009). Pembelajaran berbasis aplikasi di lapangan juga berpengaruh positif terhadap kreatifitas yang merupakan modal dasar mahasiswa untuk mandiri dalam mengatasi permasalahan yang ada Rati et al., (2017). Peningkatan ketrampilan mahasiswa juga bisa dibentuk dengan pembelajaran yang mengkombinasikan materi dengan praktek nyata di lapang Wulandari (2016) berpengaruh positif terhadap kreatifitas yang merupakan modal dasar mahasiswa untuk mandiri dalam mengatasi permasalahan yang ada Rati et al., (2017). Peningkatan ketrampilan mahasiswa juga bisa dibentuk dengan pembelajaran yang mengkombinasikan materi dengan praktek nyata di lapang. Wulandari (2016)

\section{KESIMPULAN}

Dalam penelitian ini ditarik kesimpulan bahwa pembelajaran kewirausahaan dengan menggunakan metode berbasis proyek berpengaruh terhadap minat mahasiswa dalam berwirausaha serta membentuk sikap mandiri mahasiswa untuk bertahan di masa pandemi covid-19 saat ini. Dari hasil penjaringan pendapat terhadap mahasiswa yang telah menempuh pembelajaran kewirausahaan bahwa mahasiswa sebagai pemuda dan kaum milenial sebenarnya sangat berminat untuk menjadi seorang wirausaha hanya masih sebagian saja merasakan manfaat nyata dari mata perkuliahan kewirausahaan yang diberikan. Terdapat perbedaan hasil belajar dengan hanya memberikan bahan ajar menggunakan metode ceramah dibandingkan apabila ada aplikasi ilmu secara nyata di lapangan. Pembelajaran mata kuliah kewirausahaan berbasis proyek dengan mengaplikasikan dalam praktek kerja secara nyata lebih dirasakan manfaatnya karena mahasiswa diberikan kesempatan mengembangkan pemikiran usaha ke depan melalui produk yang sudah dihasilkan bersama kelompoknya mulai dari perencanaan usaha dan keuangan secara mandiri hingga pembuatan produk serta pemasarannya. Metode pembelajaran berbasis proyek juga mampu membuat mahasiswa percaya diri dengan kemampuan yang dimiliki dalam mengembangkan pengetahuan dan juga ketrampilannya.

Saran yang sebaiknya diterapkan agar pemberian materi ajar di perkuliahan dikombinasikan dengan metode pembelajaran praktek di lapangan dengan penjadwalan minimal 1 kali dari keseluruhan tatap muka. Terutama untuk mata kuliah kewirausahaan penjadwalan praktek di lapangan bisa lebih dari 1 kali dan bisa dimungkinkan selama setengah dari keseluruhan tatap muka yang ada. Dengan metode seperti ini diharapkan dapat mengurangi rasa bosan mahasiswa dengan suasana belajar yang monoton sehingga bisa semangat dan dapat membangun rasa percaya diri serta mandiri dengan menuangkan dalam bentuk karya nyata. Pembelajaran yang nyata di lapangan sesuai dengan Permendikbud no 3 tahun 2020 yang mengatur kebijakan tentang program kampus merdeka. Setiap mahasiswa diberikan kesempatan untuk bisa mengaplikasikan ilmunya sehingga mereka siap terjun ke masyarakat dengan displin ilmu masing-masing.

\section{UCAPAN TERIMA KASIH}

Kami ucapkan terima kasih kepada Ibu Dekan, rekan -rekan dosen Fakultas Ekonomi, mahasiswa angkatan 2017/2018 yang telah mengikuti mata kuliah lab kewirausahaan serta LPPM Universitas Merdeka Pasuruan yang telah memberikan 
dukungan serta motivasi sehingga terselesainya artikel ini. Selain itu terima kasih juga kepada Pengurus Yayasan Perguruan Tinggi Merdeka Pasuruan yang telah memberikan dana hibah melalui kegiatan penelitian dan pengabdian masyarakat LPPM Universitas Merdeka Pasuruan

\section{REFERENCES}

Budi, and Fabianus F. (2018). "Pengaruh Pendidikan Kewirausahaan Dalam Menumbuhkan Minat Kewirausahaan." pengabdian dan kewirausahaan 2(issn:2581-2718)

Daryanto. (2009). Demonstrasi Sebagai Metode Belajar. jakarta: depdikbud.

Eka Wulandari, F. (2016). "Pengaruh Pembelajaran Berbasis Proyek Untuk Melatihkan Keterampilan Proses Mahasiswa.” Pedagogia 5(2): 247-54.

Farida, Eka, EriyTri D., Bambang Danu S., and Mit Wi. (2017). "Pengembangan Model Pembelajaran Kewirausahaan Berbasis Proyek Untuk Menumbuhkan Semangat Wirausaha." JPEK 1: 8-18.

Hanafiah, N. and Cucu Suhana. (2009). Konsep Strategi Pembelajaran. pt. refika aditama.

Inayah, Laili, Yusrin, and Eny W. (2019). "Pengaruh Pembelajaran PJBL Dengan Pendekatan Chemoentrepreneurship (CEP) Terhadap Minat Wirausaha Siswa." http://repository.unimus.ac.id.

Maesaroh, S. (2013). "Peranan Metode Pembelajaran Terhadap Minat Dan Prestasi Belajar Pendidikan Agama Islam.” Jurnal Kependidikan, 1(1).

Mashuri, Moch A., Shinta Devi A., and Vina N. (2020). "Peran Masyarakat Terhadap Pembangunan Ekonomi Berbasis Kampung Tangguh Sebagai Upaya Menekan Angka Covid-19." Makro Manajemen 5(2). doi: http://dx.doi.org/10.36467/makro.g.05.02.04

Mulyani, E. (2014). "Pengembangan Model Pembelajarana Berbasis Projek Pendidikan Kewirausahaan Untuk Meningkatkan Sikap, Minat, Perilaku Wirausaha, Dan Prestasi Belajar Siswa SMK." Cakrawala Pendidikan (1)

Prihatini, E. (2017). "Pengaruh Metode Pembelajaran Dan Minat Belajar Terhadap Hasil Belajar IPA.” Jurnal Formatif 7(2). issn: 2088-351X.
Rati, Ni W., Nyoman K., and Nyoman R. (2017). "Model Pembelajaran Berbasis Proyek, Kreatifitas Dan Hasil Belajar Mahasiswa." Pendidkan Indonesia 6(1): 60-71.

Satrionugroho, B., and Didik N. (2015). "Analisa Pengaruh Mata Kuliah Kewirausahaan Terhadap Minat Wirausaha Mahasiswa Stmik Sinar Nusantara." ilmiah sinus 13(issn:1693-1173).

Sulasari, A. (2016). "Pengembangan Metode Pembelajaran Kewirausahaan Berbasis Proyek.": 15. www.researchgate.net.

Suryana. (2003). Memahami Karakteristik Kewirausahaan. Direktorat Jenderal Pendidikan Dasar dan Menengah Departemen Pendidikan Nasional.

Takdir, Dedy, Mahmudin A., and Sudirman Z. (2015). Kewirausahaan.,

ConflictofInterestStatement:The authorsdeclare that theresearchwas conducted in the absence of any commercial or financial relationships that could be construed as a potential conflict of interest.

Copyright (C) 2021 Erwantiningsih, Wahyuni, and Immadudin. This is an openaccess article dis- tributed under the terms of the Creative Commons Attribution License (CC BY). The use, distribution or reproduction in other forums is permitted, provided the original author(s) and the copyright owner(s) are credited and that the original publication in this journal is cited, in accordance with accepted academic practice. No use, distribu- tion or reproduction is permitted which does not comply with these terms. 


\section{LIST OF TABLE}

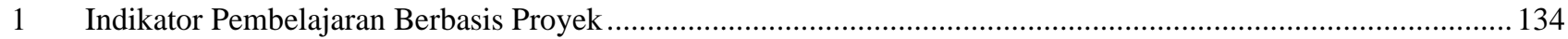

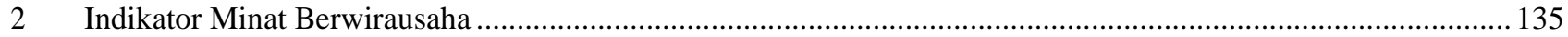

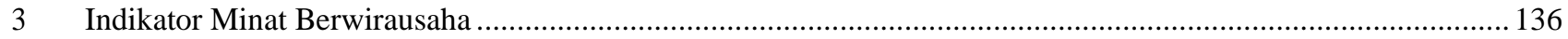

4 Pengaruh Pembelajaran Berbasis Proyek terhadap Minat Berwirausaha........................................................ 137

5 Pengaruh Pembelajaran Berbasis Proyek terhadap Kemandirian .................................................................. 138 
TABLE1 / Indikator Pembelajaran Berbasis Proyek

Variabel

Pembelajaran Berbasis Proyek
Bentuk

Kuesioner

\begin{tabular}{lc}
\multicolumn{1}{c}{ Indikator } & No \\
dorongan menemukan masalah & p10 \\
identifikasi dan mencari jalan keluar & p11 \\
belajar bersama membuat starategi dan konsep & p13 \\
mengumpulkan informasi,penerapan teknologi & p14 \\
membuat perencanaan kerja (bisnis plan) & p15 \\
merencana usaha dan kalkulasi kebutuhan & p16 \\
membuat produk sesuai rencana kerja & p17 \\
memaksimalkan kualitas berdasar rencana & p18 \\
menguji kelebihan dan kelemahan produk & p19 \\
mencari jawaban kelebihan/kekurangan produk & p20 \\
presentasi untuk kemungkinan kritik dan saran & p21 \\
presentasi mengembangkan pemikiran usaha & p22 \\
\hline
\end{tabular}


TABLE2/ Indikator Minat Berwirausaha

Variabel

Minat Berwirausaha
Bentuk

Kuesioner
Indikator

Tertarik berwirausaha setelah lulus

suka berwirausaha daripada menjadi karyawan

yakin memulai usaha dalam1-2 tahun mendatang

yakin bisa mengelola waktu dan disiplin

ingin menjadi bos dan mengatur diri sendiri

ingin wirausaha karena keluarga mendukung

berwirausaha meneruskan usaha keluarga

kurikulum wirausaha membantu meningkatkan keinginan

berwirausaha

minat meningkat setelah mengikuti perkuliahan
No

p1

p2

p3

p4

p5

( 6

p7

p8

p9 
TABLE3/ Indikator Minat Berwirausaha

Variabe

Kemandirian Kuesioner
Indikator

Belajar kewirausahaan atas kemauan sendiri

percaya pada kemampuan diri sendiri

Tertantang menyelesaikan tugas

Menyelesaikan laporan sesuai jadwal

Menanyakan dan menyelesaikan tugas tanpa disuruh p24

p25

p26

p27 


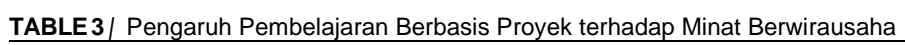

Model

1

\section{(Constant)}

Pembelajaran Berbasis Proyek
Unstandardized Coefficients

.738

.669

Std. Error

.370

.121
Standardized

Coefficients

Beta

.587 $\mathrm{t}$

Sig.
1.993

.051

5.517

.000

a. Dependent Variable: Minat Berwirausaha 
TABLE 4 / Pengaruh Pembelajaran Berbasis Proyek terhadap Kemandirian

\section{Coefficients $^{a}$}

Model

Pembelajaran Berbasis Proyek

a. Dependent Variable: Kemandirian
Unstandardized Coefficients

B

.598

696
Std. Error

.355

.116
Standardized

Coefficients

Beta

.618 t

Sig.

5.993
.097

.000 


\section{LIST OF FIGURE}

1 Desain Penelitian

2 Diagram Indikator Pembelajaran Berbasis Proyek.

3 Diagram Indikator Minat Berwirausaha

4 Diagram Indikator Minat Berwirausaha

Pengaruh Pembelajaran Berbasis Proyek terhadap Kemandirian

6 Pengaruh Pembelajaran Berbasis Proyek terhadap Minat Berwirausaha. 


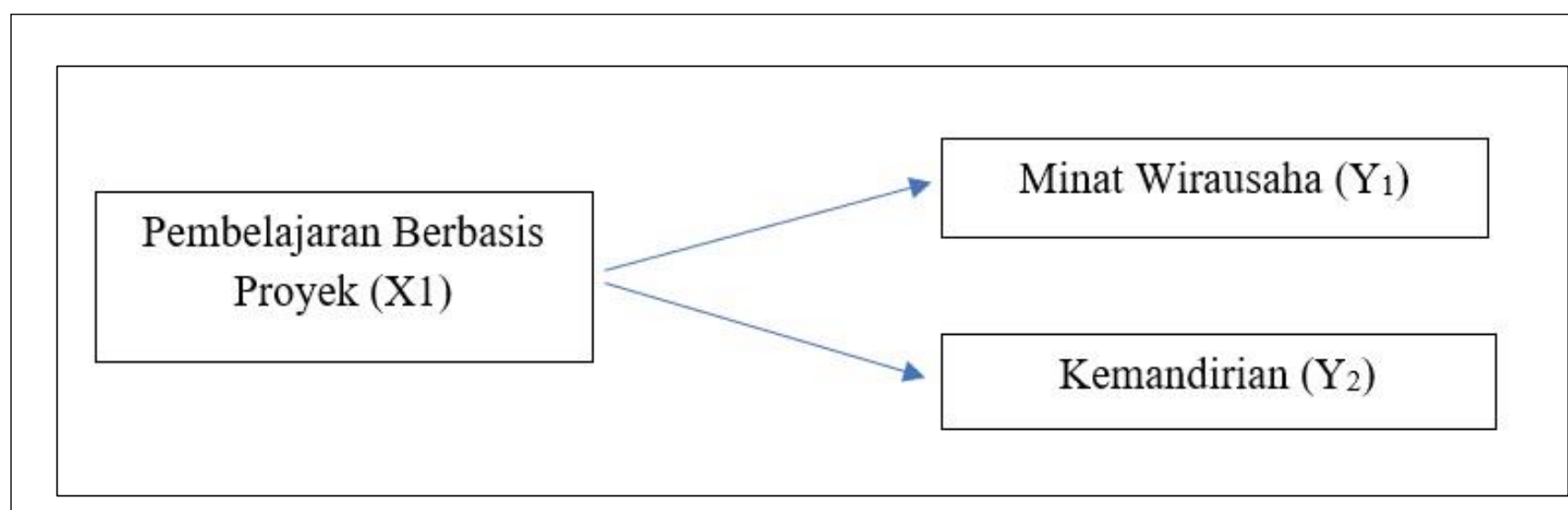

FIGURE 1 / Desain Penelitian 


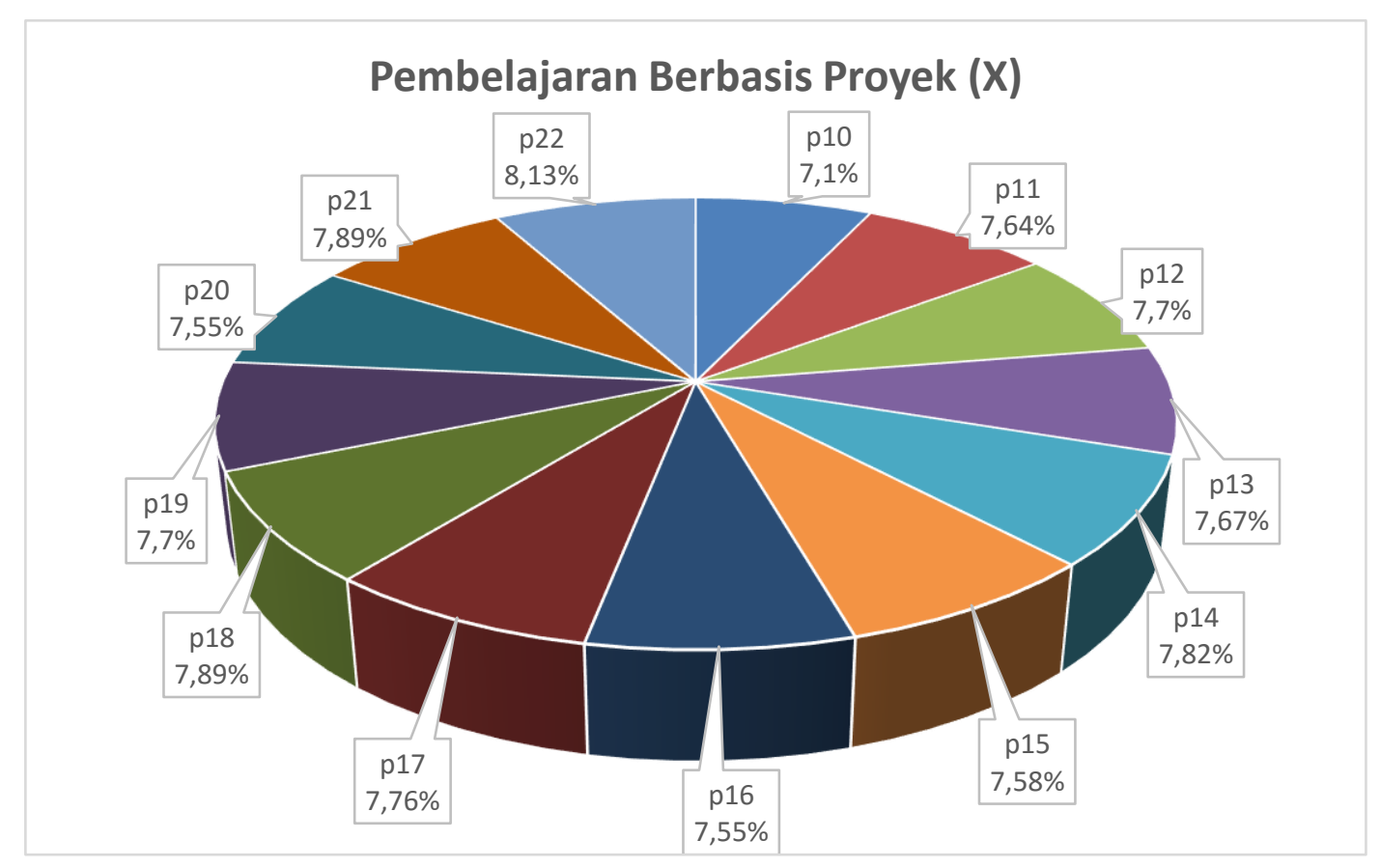

FIGURE 2 / Pembelajaran Berbasis Proyek 


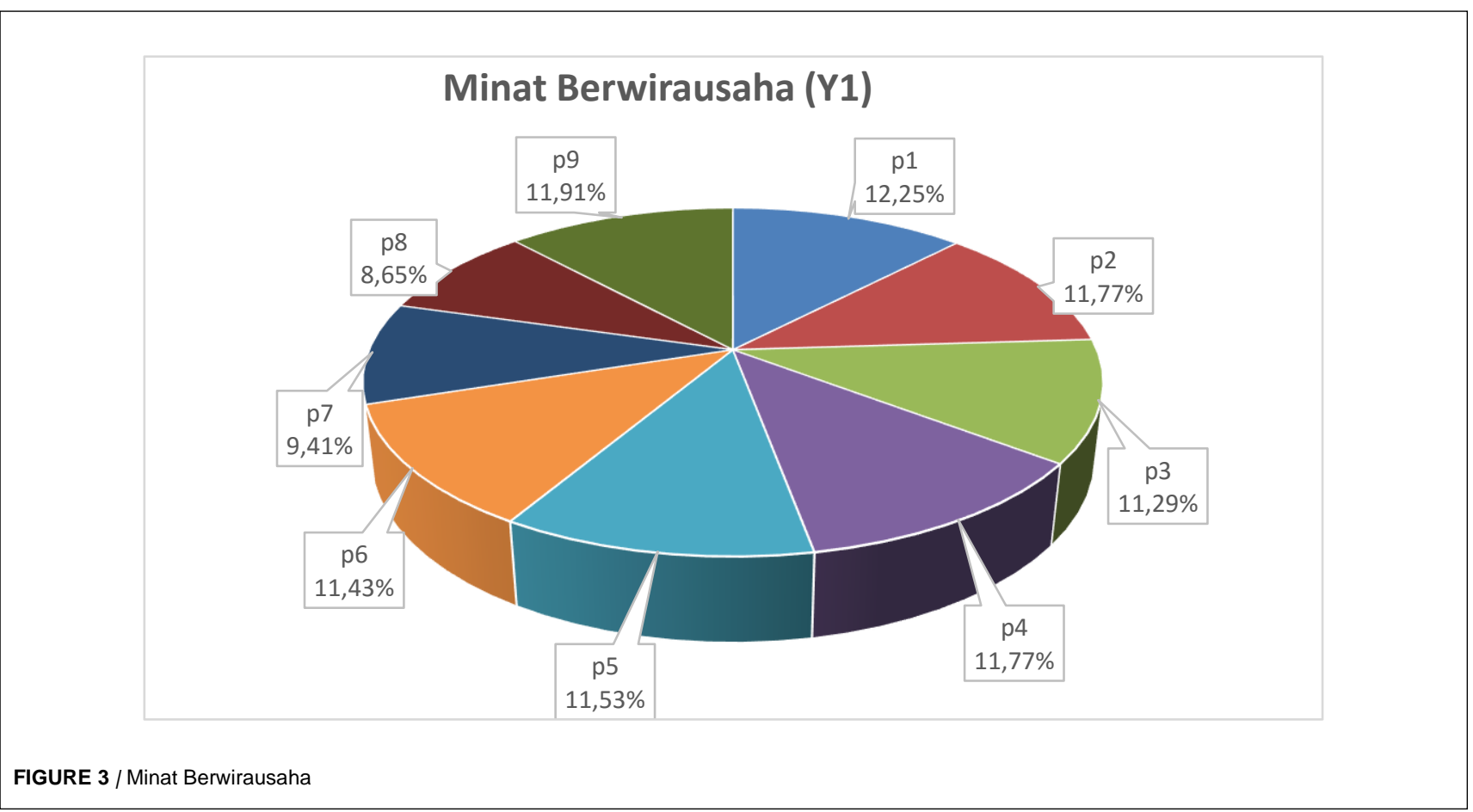




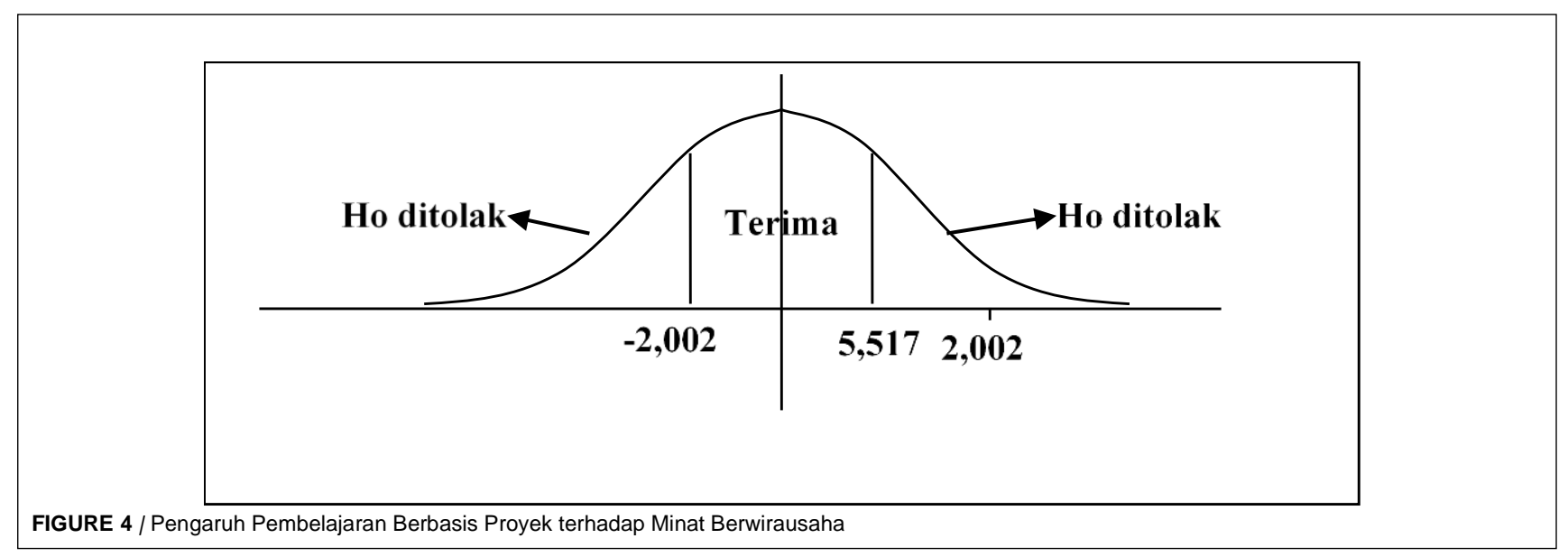




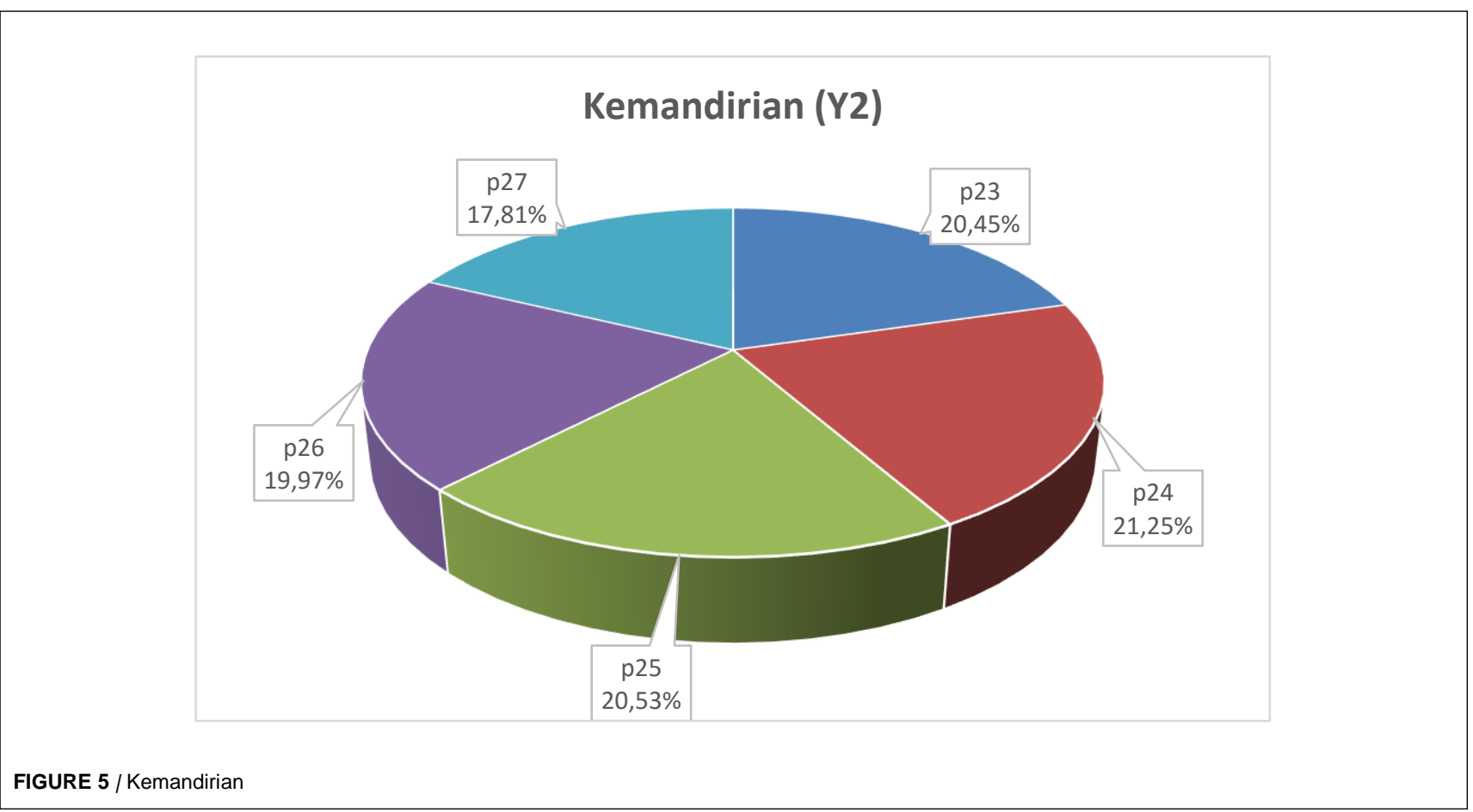




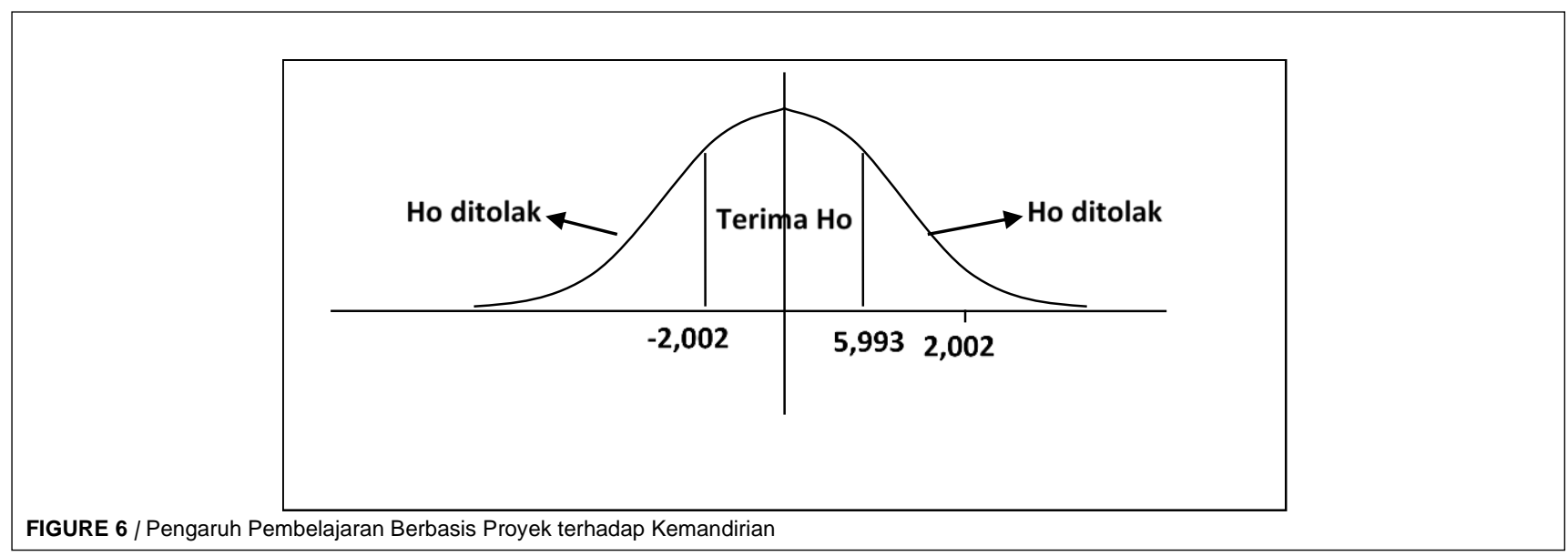

